\title{
Does EU Law Recognize Legal Limits to Integration? Accommodating diversity and its limits
}

\author{
Leonard F.M. Besselink ${ }^{1}$
}

\section{Abstract}

The integration of legal and constitutional orders in the European Union requires unity of action. In the abstract, one may easily answer the question whether unity of action entails the necessity of uniformity either in approach or in result, in the negative. An obvious alternative to uniformity would be the accommodation of diversity. But does EU law recognize diversity as a matter of law? If so, to what extent? Does this diversity also function as a limit to integration?

These are the questions that I address in this essay. The four parameters of this paper are therefore 'unity of action', 'uniformity', 'accommodation of diversity' and 'limits to integration'. The focus is primarily concerned with the relation between these four notions. They 'frame' the questions and although it provides some answers, its foremost aim is to make the case for the accommodation of legitimate diversity and indicating the limits of such accommodation. In doing so, this paper outlines forms and some of the techniques of such accommodation, without derailing into a full analytic description of them, as this would severely overstep limits of space and time.

\section{A. Integration and the requirement of uniformity}

European integration was conceived as a means to overcome and do away with obstacles to peace in Europe, first of all peace between states. The divisions of Europe were to be overcome by unity. This in turn was to be

1 Leonard Besselink holds the chair of constitutional law and is attached to the Amsterdam Centre for European Law and Governance (ACELG), Faculty of Law, University of Amsterdam. 
achieved by removing obstacles to welfare in Europe, starting off with the creation of a customs union, towards a 'common market', and an 'internal market without boundaries', as it was later rephrased. From what is common in a single market, a community and subsequently a union were to arise; European integration was to lead to the creation of a European Union.

A big question, however, is whether integration must necessarily mean uniformity, as may have been the main intuition in establishing a single market initially. This question has become all the more pressing in the course of time. This also transpires, as is demonstrated in the following section, from a comparison of the various preambles of the founding treaties. In this section, we also briefly reflect on the political justification of indeed considering accommodation of diversity, rather than imposing mere uniformity, of prime importance for European integration.

\section{The development through the preambles: from union to diversity}

Looking at the various preambles, we cannot fail to notice that in the EEC Treaty the idea of unity was dominant. The preamble was about 'an ever closer union' (first recital), 'common action' (second recital) and 'concerted action' (fourth recital), 'the unity of [the member states'] economies' (fifth recital), and the 'pooling of their resources to preserve and strengthen peace and liberty' (eighth, penultimate recital).

The European Union Treaty as concluded in Maastricht strikes a different note in this respect. It combines the desire 'to deepen solidarity between [member states'] peoples' with 'respecting their history, their culture and their traditions' (fourth recital out of eleven). This sudden counterbalancing occurs in the context of a preamble which opens with the resolution to mark 'a new stage in the process of European integration'; it then recalls the 'historic importance of the ending of the division of the European continent' (second recital), thus referring to the 'fall of the Wall' as the 'end' of the divided Europe. There is an awareness of a new historical situation, and this may explain the political recalibration of the relation between unity and diversity.

The new 'balance' is also evident from the preamble to the Charter of Fundamental Rights of the European Union, solemnly proclaimed on 7 December 2000, which was a part of the Charter that remained unaltered at the time of the Constitutional and the Lisbon Treaty. In the third of six recitals it states that the Union contributes to the preservation and to the 
development of common values "while respecting the diversity of the cultures and traditions of the peoples of Europe as well as the national identities of the Member States and the organisation of their public authorities at national, regional and local levels'; this is followed by the statement of the aim 'to promote balanced and sustainable development and [to ensure] free movement of persons, goods, services and capital, and the freedom of establishment.' So diversity comes first, the uniting forces of the free movement rights second.

The Treaty on a Constitution for Europe's preamble was even more marked than that of the Maastricht Treaty by the move from emphasis on unity towards the recognition of the value of diversity. The third recital (out of six) begins by emphasizing that the way in which 'the peoples of Europe are determined to transcend their former divisions and, united ever more closely, to forge a common destiny' is that of 'remaining proud of their own national identities and history' - this pride takes syntactical precedence over the ever closer union and common destiny. ${ }^{2}$ The fourth recital continues by incorporating the EU motto in the famous words: '[T]hus "United in diversity", Europe offers them the best chance of pursuing $[\ldots]$ the great venture which makes of it a special area of human hope'.

Perhaps somewhat surprising, given the criticism of the (for some) too high constitutional ambitions, is that the Lisbon Treaty, comparatively speaking, downplayed the value of diversity in its preamble a little. It refers neither to national history and identity, nor to diversity. It has retained the reference to deepening solidarity between member states 'while respecting their history, their culture and their traditions'. Although there is little further mention of diversity in the Lisbon Treaty's preamble, the motto chosen in 1999 for the EU was 'unity in diversity', a year later adopted in slightly adapted form as 'united in diversity' by the EU institutions. This motto was explicitly referred to in the abortive Constitutional Treaty as one of the symbols of the EU, but not at all in the Lisbon Treaty -it is ironic that in the zeal to divest the latter of all

2 There are slight variations. The German version says 'dass die Völker Europas, stolz auf ihre nationale Identität und Geschichte, entschlossen sind, die alten Gegensätze zu überwinden', and the Italian 'pur restando fieri', while the Spanish reads 'sin dejar de sentirse orgullosos', the French 'tout en restant fiers de leur identité et de leur histoire nationale', the English 'remaining proud' and the Dutch 'onverminderd trots'. 
constitutional symbolisms, also a strong reference to diversity was obliterated.

\section{Legitimating diversity: democracy}

The respective preambles also demonstrate a varied expression and articulation of traditional political values of the western world.

The EEC Treaty, although drafted in the heyday of the Cold War, barely refers to such values. It is only in the penultimate recital that it is made clear that pooling of resources is 'to preserve and strengthen peace and liberty'. Apart from a reference to the relations between the European and overseas countries of member states, ${ }^{3}$ there is no further reference to political values.

For understandable reasons, this was different with the EU Treaty concluded in Maastricht in 1992. The new geo-political situation in Europe and the urge towards a more political Union is evident from the much more prominent references to the political preconditions of western society, which thus far had been mentioned only towards the end of the EEC preamble. The second recital expresses 'the need to create firm bases for the construction of the future Europe' and is immediately followed by the confirmation of the 'attachment to the principles of liberty, democracy and respect for human rights and fundamental freedoms and of the rule of law' (third recital); then follows the already quoted recital on solidarity while respecting the history, culture and traditions of the member states.

The Treaty on a Constitution for Europe had as its very first recital the invocation of 'the universal values of the inviolable and inalienable rights of the human person, freedom, democracy, equality and the rule of law'.

In the Treaty of Lisbon this became the second recital, and also retained the recital from the earlier EU Treaty on 'the attachment to the principles

3 The preceding recital was devoted to the relations between the European countries to their overseas countries and their prosperity and the commitment to the UN Charter in that respect. This, like the relatively few remaining overseas countries and territories, is something of a relic of the past. Note though that the Netherlands has re-colonized the three smallest of their six Caribbean islands, one of them even against the wishes of the population, by re-incorporating them into the country of the Netherlands as a kind of municipality per 10 October 2010. The EU Treaties do not apply to them, however, except for Part IV of the TFEU (on Association of the Overseas Countries and Territories). 
of liberty, democracy and respect for human rights and fundamental freedoms and of the rule of law'. The 'ever closer union' is now in the penultimate of fourteen recitals.

All this suggests a positive correlation between the more political nature of the stage of European integration, the mention of the political values underlying the Union and the mention of diversity rather than of commonality and overcoming obstacles between peoples of member states. The latter type of expressions that occurred in the preamble of the EEC Treaty have not been retained in the EU Treaty but in the Treaty on the Functioning of the Union. This suggests that the unity is in the action more than in the principle; it is a means rather than an end.

This is not surprising. Democracy is in many ways the greatest of challenges in and of Europe, but there can be no doubt, either politically or legally, that the Union must be founded on democracy (cf. Art. 2 TEU).

In a Union in which the citizens derive their status as citizens from belonging to a member state, and whose citizenship is politically characterized by participating both (and perhaps more strongly so) in the member state polity as well as in the Union, democracy is itself plural. This has as an immediate consequence that at a stage of European integration, and in a constellation in which there is no neat and definitive division of political competence over the various actors in respective fora, but much rather a mixture, entwining and fluidity of political theatres and actors, the outcome of the articulation of what constitutes a desirable course of action can diverge with regard to many, if not most, issues.

Democracy is deeply rooted in the respect for diversity of opinion as to the desirable course of public action. This must entail at least some respect for diversity of action resulting from the authentically democratic expression of such preferences, not only for private citizens, but also for public authorities: democracy can be meaningful only if it translates into action.

Unity of action of the EU remains, therefore, necessarily in tension with the legitimate democratic action of member states. But unity of EU action and legitimate democratic action of member states do not exclude one another. This is the case as long as one is prepared to acknowledge that common action does not always and necessarily require absolute uniformity. To the contrary, the integration of legal and constitutional orders requires the accommodation of diversity.

Due respect for the core objectives of integration in the framework of the EU as well as respect for fundamental orientations of democratic member states under the rule of law must be at the basis of integration. 
Unity of action without which integration would be impossible may often require uniformity, but in a democracy of the kind we enjoy in the EU it certainly also requires the accommodation of diversity.

\section{B. Does EU law as a matter of law recognize diversity, and is this a legal limit to integration?}

So far we have looked at the realities of diversity in the democratic context of the EU in a mainly normative and political sense. We now turn to the question whether and how EU law recognizes diversity in the broad sense in which we have framed it. We look at the matter, distinguishing general principles and norms which can be considered techniques of accommodating diversity, and more specific clauses in the EU Treaties. In the following sections we only briefly look at the primary law, legislative and judicial aspects of this, and leave the executive aspect aside.

I. General principles as techniques for accommodating diversity and their 'limiting' role

- The principle of conferral

A first general principle we deem relevant, and enshrined in the EU Treaty (Art. 3), is the principle of attributed powers or conferral. The EU has no powers except those that have been conferred upon it. This provides the outer limit of what the EU institutions can do, and provides in a sense protection to the diverse manners in which the member states and their authorities wish to pursue their own political goals in accordance with their autonomous democratically legitimated preferences.

The national side to this is the very act of attributing powers through the attendant mechanisms of approval by national legislatures and in national referenda. The conferral of powers to the EU can be likened to the changes in powers attributed to national authorities and require constitutional amendment.

This outer limit of EU competence is watched over in member states by scrutiny of the action of EU institutions aimed at ascertaining whether they have remained within the powers conferred. As is well known, this is also judicially controlled in some member states, notably in Germany, Poland and Denmark, but over time with a gradually higher threshold before courts can actually engage in such ultra vires scrutiny. 
- Limited positive integration

In the field of positive integration measures, the spectrum of integration techniques ranges from mere consultation via coordination and harmonization to uniformity of normative standards (unification of law). Where an EU competence exists this does not necessarily mean total harmonization. In fact harmonization is sometimes ruled out explicitly, as described in Article 2(5) TFEU; this applies for instance in the field of education and culture, which we mention below. ${ }^{4}$ Also, derogations from harmonisation measures are sometimes allowed. ${ }^{5}$

The choice the EU legislature can make for one instrument rather than another may influence the possibilities of accommodating diversity and avoid uniformity. This is for instance the case with the choice between a directive and regulation, the former in principle allowing for a degree of diversity in the manner of achieving the result prescribed in the directive. Other techniques which may operate to the effect of accommodating diversity are techniques such as the Open Method of Coordination, and also 'mutual recognition' is of course a way of acknowledging legitimate diversity.

- The legitimate restrictions to free movement rights

'Negative' integration is rights based, and particularly on the free movement rights. These allow for differentiation, however, particularly due to the public policy exception. Among prime examples is the Omega judgment, which concerned the case of a prohibition by the mayor of Bonn of laser games in which people target other persons as victims, simulating to kill them to win the game. The legal basis for the prohibition was the fundamental rights notion of human dignity. ${ }^{6}$ Here the ECJ explicitly held:

'[37] It is not indispensable [..] for the restrictive measure issued by the authorities of a Member State to correspond to a conception shared by all Member States as regards the precise way in which the fundamental right or legitimate interest in question is to be protected. [...]

38 On the contrary, as is apparent from well-established case-law subsequent to Schindler, the need for, and proportionality of, the provisions adopted are not

4 Art. 165(4), 166(4), and 167(5) TFEU; see also Art. 19(2), 79(4), 84, 149, 152(2a), 168(5), 173(3), 189(2), 195(2), 196(2), 197(2), 207(6), 352(3) TFEU.

5 See Art. 114(4) to (8) TFEU.

6 ECJ, Case C-36/02 - Omega Spielhallen- und Automatenaufstellungs-GmbH v Oberbürgermeisterin der Bundesstadt Bonn, ECR 2004, I-9609. 
excluded merely because one Member State has chosen a system of protection different from that adopted by another State[..].'

In this case, the Court found it of particular significance that the public policy exception at stake was grounded on a constitutional requirement, in this case guaranteeing the level of human dignity required by the relevant provision of the German Grundgesetz, and that was in its view not disproportionate:

'[39] In this case, it should be noted, first, that, according to the referring court, the prohibition on the commercial exploitation of games involving the simulation of acts of violence against persons, in particular the representation of acts of homicide, corresponds to the level of protection of human dignity which the national constitution seeks to guarantee in the territory of the Federal Republic of Germany. It should also be noted that, by prohibiting only the variant of the laser game the object of which is to fire on human targets and thus 'play at killing' people, the contested order did not go beyond what is necessary in order to attain the objective pursued by the competent national authorities.'

- The differentiation of jurisdictional powers

The Courts of the EU as well as the Member State courts each have their own remit, a sphere within which they are competent to adjudicate certain matters. Just as the ECJ cannot adjudicate whether acts under EU law are constitutional in terms of a particular national constitutional arrangement (though it may take it into account), so a national constitutional court can usually only take as relevant touchstone national constitutional law (although under it may, and may have to, take into account European and international law, which may in some jurisdictions incorporate European or international law as relevant national constitutional standard).

At the points at which these jurisdictions touch or even overlap, claims made under 'the other' jurisdiction are taken on board to the extent that these can be 'translated' into the law which is within the jurisdiction of the relevant court.

This is to some extent the case in Omega. It was the ECJ that was willing to accept the fact that 'human dignity' is a concept of much greater and central legal importance in the German constitutional order than in other member states, where such laser games have never been prohibited based on motives of human dignity. But it merely takes note of this state of affairs under national law: it is a matter for the national court to decide the particular national constitutional rights involved; it is then for the ECJ which determines the consequences of this state of affairs under EC law. In this case it was held that is was indeed an authentic matter of 'public policy' which lived up to the EU law requirements of proportionality in 
light of the particular meaning of the concept of human dignity in German constitutional law; in other words, it translated the German constitutional concern into EU law concepts.

Similarly, in the Sayn Wittgenstein case we see that a claim under national constitutional law prohibiting the carrying of noble titles was translated into an appeal to both 'constitutional identity' under Art. 4(2) TEU, and into a public policy exception to the free movement of citizens under Art. 20 TFEU: both EU law legal concepts. In this case, in the framework of the review of the proportionality of the restriction, the ECJ referred to the constitutional identity clause in order to establish that the restriction was proportional. But the cue came from the particular constitutional arrangement and its importance in Austria (and only some other member states). ${ }^{7}$

Clearly, Omega and Sayn Wittgenstein achieve the accommodation of quite diverse national values which are not shared by all member states, and which lead to a differentiated application of EU law.

Sometimes the distinction of jurisdictional spheres of competence leads to courts refraining from entering into a matter within the jurisdiction of another court. This can be a way of avoiding a clash and in a sense accommodating diversity. This would seem - at least sometimes - to be the case when the ECJ in its case law leaves the application of certain principles it establishes as, so to say, guidelines for the referring court (in contrast to other cases in which, for all intents and purposes (though not formally), it does so itself). There are various degrees in which this technique (if we may call it that) is applied in practice, of which Familia Press $^{8}$, is one version and the more clamorous version is exemplified by Rottmann ${ }^{9}$.

In Familia Press the Court acknowledged that the restriction of the free movement of goods (in this case foreign periodicals with prize winning puzzles) can be justified by overriding requirements of public interest,

7 ECJ, Case C-208/09 - Ilonka Sayn-Wittgenstein v Landeshauptmann von Wien, ECR 2010, I-13693. For a further in-depth analysis, see Besselink, Respecting Constitutional Identity in the EU. A Case Note (An Essay on?) to ECJ (Second Chamber), Case C 208/09, 22 December 2010, Ilonka Sayn-Wittgenstein v Landeshauptmann von Wien, Common Market Law Review 2012, vol. 49, no. 2, p. 671-693.

8 ECJ, Case C-368/95 - Vereinigte Familiapress Zeitungsverlags- und vertriebs GmbH and Heinrich Bauer Verlag, ECR 1997, I-3689.

9 ECJ, Case C-135/08 - Rottmann, ECR 2010, I-1449. 
provided that these justifications comply with the freedom of expression. It gave some instructions as to how this compliance with both the free movement of goods provision (then Art. 30 EC) and the freedom of expression was to be understood, next leaving it to the national court to determine whether those conditions are satisfied on the basis of a study of the national press market concerned. So here the Court provided fairly detailed instructions to the national court, which, however, had to apply the abstract criteria in the context of a proportionality assessment to the concrete case at hand, thus leaving the solution of the case underdetermined.

In Rottmann, the Court decided that the withdrawal of the naturalization of a member state citizen because of deception that leads to statelessness and hence the loss of EU citizenship, is a matter within the ambit of EU law and is amenable to judicial review under EU law. It furthermore held that in principle withdrawal for the indicated reason was legitimate, but that it was up to the national court to determine whether the consequence in practice was proportional - thus devolving the gist of the matter to national courts.

\section{Specific clauses}

In this section we sum up the three specific manners in which the accommodation of diversity is given a place in EU primary law: specific clauses on various forms of 'cultural' diversity, the 'national identity' clause and Article 53 of the EU Fundamental Rights Charter.

- 'Diversity' in the Treaties

Far from spurned, diversity is cherished. In Article 3(3) TEU the obligation to 'respect its rich cultural and linguistic diversity' is formulated. Linguistic and cultural diversity are mentioned in Treaty provisions in the particular fields of education (Art. 165 TFEU) and the trade in cultural and audio-visual services (Art. 207(4) sub a TFEU); national and regional diversity are mentioned in the area of promoting culture and bringing out the common cultural heritage (Art. 167 TFEU). The Treaties also recognize socio-political specificities such as the diversity of national systems as regards the role of social partners (Art. 152 TFEU); 'the diversity of situations in the various regions of the Union' must be taken 'into account' in the environmental policy of the Union (Art. 191 TFEU). 
There are also the somewhat more covert but no less important ways in which in the operation of free movement rights, linguistic, cultural and other forms of diversity are sometimes at stake and to various degrees taken into account.

\section{- 'National identity'}

Probably the most explicit recognition of the value of diversity in a strong politico-constitutional sense is found in the national identity clause of Article Art. 4(2) TEU, which is a reformulation of the original version of the Treaty of Maastricht, that became legally binding with the entry into force of the Lisbon Treaty. This reformulation could already be found in the Constitutional Treaty and reads:

'The Union shall respect the equality of Member States before the Treaties as well as their national identities, inherent in their fundamental structures, political and constitutional, inclusive of regional and local self-government. It shall respect their essential State functions, including ensuring the territorial integrity of the State, maintaining law and order and safeguarding national security. In particular, national security remains the sole responsibility of each Member State.'

The first sentence has been the object of a recent spate of doctrinal analysis. ${ }^{10}$ This is in part triggered by the references to national identity or constitutional identity made by national constitutional courts (particularly the Spanish Tribunal Constitucional, the Conseil constitutionnel, the

10 E.g. Besselink, National and constitutional identity before and after Lisbon, Utrecht Law Review 2010, vol. 6, issue 3, p. 36-49, available at http://www.utrechtlawreview.org/index.php/ulr/article/viewFile/139/135 (checked 06/11/2013); von Bogdandy/Schill, Overcoming absolute primacy: respect for national identity under the Lisbon Treaty, Common Market Law Review 2011, vol. 48, p. 1417 et seq.; Millet, L'Union européenne et l'identité constitutionnelle des États membres, 2013, p. 386 et seq. ; Kröll, The European Court of Justice, a Guardian ('Hüter') of the Republican Principle of the Austrian Federal Constitution?, ICL Journal (Vienna Journal on International Constitutional Law) 2012, vol. 6, no. 1, p. 110 et seq.; Preshova, Battleground or Meeting Point? Respect For National Identities in the European Union - Article 4(2) Of The Treaty On European Union, Croatian Yearbook of European Law \& Policy 2012, vol. 8, p. 267 et seq.; Guastaferro, Beyond the Exceptionalism of Constitutional Conflicts: The Ordinary Functions of the Identity Clause, Yearbook of European Law 2012, vol. 31, no. 1, p. 263-318; Cloots, National Identity of Member States and the European Court of Justice (to be published). 
Bundesverfassungsgericht, the Polish Trybunal Konstytucyjny, the Czech Ústavní Soud), and perhaps more so by the ECJ's positive application of the clause in cases such as Sayn Wittgenstein and (less prominently) Runevic Wardyn.

It has been argued convincingly that this clause was reformulated not with 'extra-ordinary' constitutional conflicts, but the ordinary EU decision-making in mind. To use terms derived from Bruce Ackerman, it was framed not so much as an instrument in 'constitutional politics' but with 'ordinary politics' in mind, especially the division of powers between member states and EU. ${ }^{11}$ Thus, the identity clause would at least potentially have an important role to play in safeguarding Member States' cultural diversity, regulatory autonomy, and margin of appreciation in the operation of the internal market. In line with what has been submitted so far in this essay, this would appear to be correct. The question is nevertheless whether the functioning of the identity clause stops here, or whether it can also function as a limit to European integration, which would of course and necessarily be only in extreme cases of constitutional conflict, that is to say, when in the ordinary decision-making process respect of the identity clause has not been secured (though respect might ordinarily be assumed).

I would argue that the latter is the case: it also applies as a legal limit to European integration.

Without unnecessarily repeating all that could be adduced to this effect, ${ }^{12}$ let us recapitulate the main reasons why.

The starting point should be the plain language of the provision: the Union 'respects' the national identity inherent in the political and constitutional structures of member states. Of course, there is very much that is, both at an abstract level and to a large degree also in practical detail, a core that is common to the member states. But among things which member states consider an important part of their identity there are clearly differences and some of them are either shared with all other member states, or considered equally part of their identity. This is for instance the case with the particular republican or non-republican, federal or unitary form of the state, or the importance of the exclusiveness or inclusiveness of language. Whenever a decision is taken by the EU

11 Guastaferro (note 10).

12 See on this Besselink (note 7). 
institutions which turns out to be in conflict with the national identity clause, the duty to respect would be deprived of legal meaning unless it implies that the EU measures have to recede and cannot be effectively applied. Whether one would call this a 'restriction of EU law primacy' or not, is a matter over which one may argue either way without this changing the conclusion that it leads in pertinent cases to the disapplication of an EU measure. ${ }^{13}$ Nor is it decisive that in the ECJ case law so far the Court has translated the appeal to national core constitutional values into the language of substantive EU law, notably the exceptions to the free movement rights. Whether the ECJ did so convincingly or unnecessarily - as regards Sayn Wittgenstein ${ }^{14}$ I maintain the latter - again does not change the ultimate effect of its reasoning: that the national value, even if not common to the member states nor part of the EU identity, is accommodated by letting it prevail over the free movement right at issue.

Of course, the ultimate proof of the pudding would be in a case of the alleged invalidity of an EU measure resulting from an alleged conflict with the duty to respect the constitutional identity of a member state. Realistically, it is indeed not something that the Court would be very likely to conclude too easily - and this is not only because the Court rarely ever declares the invalidity of a measure of secondary EU law, as can be intimated from the approach it takes to Article 53 of the Charter.

- Art. 53 Charter: where EU and member state fundamental rights diverge

The old issue of how to solve a situation in which a national fundamental right provides a higher level of protection to a citizen or private party than the EU rights, gives rise to quite similar doubts and questions as those concerning national and constitutional identity. ${ }^{15}$ The classic international

13 The identity clause is a rule of EU law and therefore one might say that even in the situation sketched it prevails. To the extent that the principle of respect for national identity is a matter of national law, this must be viewed differently. Personally, I consider the identity clause to be a norm shared between the EU and national constitutional order, which therefore can govern their mutual relationship without them being the exclusive property of either legal order.

14 See Besselink (note 7).

15 See for a treatment of the issue long before the Charter was more than only dreamt of, Besselink, Entrapped by the Maximum Standard: On Fundamental 
human rights conventions contained clauses on such situations, which in a rather special way seemed at first sight to be emulated by Article 53 of the Charter:

Nothing in this Charter shall be interpreted as restricting or adversely affecting human rights and fundamental freedoms as recognised, in their respective fields of application, by Union law and international law and by international agreements to which the Union or all the Member States are party, including the European Convention for the Protection of Human Rights and Fundamental Freedoms, and by the Member States' constitutions.

In the past, there has been a certain body of speculation as to what this might mean or not. ${ }^{16}$ We now have the first directly relevant case law in the form of the ECJ's judgment in Melloni. ${ }^{17}$ This judgment seems to put down hopes that Article 53 might be a method for accommodating legitimate diversity. It seems to strengthen the view that within the scope of EU law, no diversity is allowed to the benefit of citizens if it is not granted by EU law itself but by national constitutional law.

The case concerned the situation that the Spanish constitutional standards for trial in absentia provided more protection than the EU standard and conflicted with the rules on the European Arrest Warrant (Framework Decision 2009/299). The referring Spanish Constitutional Tribunal wished to know whether Article 53 of the Charter would allow it to apply the higher national standard.

Rights, Pluralism, Subsidiarity in the European Union, Common Market Law Review 1998, vol. 35, no. 3, p. 629-680.

16 Besselink, The Member States, the National Constitutions and the Scope of the Charter, Maastricht Journal of European and Comparative Law 2001, vol. 8, no. 1, p. 68-80; Weiler, The Constitution of Europe, 1990, p. 123-128; Widmann, Article 53: Undermining the Impact of the Charter of Fundamental Rights, Columbia Journal of European Law 2002, vol. 8, p. 342; Bering Liisberg, Does the EU Charter of Fundamental Rights Threaten the Supremacy of EU Law? Article 53 of the Charter: a Fountain of Law or Just an Inkblot, Jean Monnet Working Paper 4/01 (republished in Common Market Law Review 2001, vol. 38, no. 5, p. 1171-1199); Avlbej, Fundamental human rights as an exception to the freedom of movement of goods, Jean Monnet Working Papers 06/04, p. 36-51; Torres, Conflicts of rights in the European Union : a theory of supranational adjudication, 2009, p. 208; de Witte, Tensions in the multilevel protection of fundamental rights: the meaning of article $53 \mathrm{EU}$ Charter, in Citizenship and Solidarity in the European Union - from the Charter of Fundamental Rights to the Crisis, the State of the Art, in: Silveira/Canotilho/Froufe(eds.), (to be published).

17 ECJ, Case C-399/11 - Melloni. 
The ECJ took its starting point in primacy in the sense of the classic Internationale Handelsgesellschaft and Simmenthal case law, in order to stress the impossibility of diversity in terms of higher protection of rights:

59 It is settled case-law that, by virtue of the principle of primacy of EU law, which is an essential feature of the EU legal order [...], rules of national law, even of a constitutional order, cannot be allowed to undermine the effectiveness of EU law on the territory of that State (see, to that effect, inter alia, Case 11/70 Internationale Handelsgesellschaft [...] and Case C 409/06 Winner Wetten [...].

60 It is true that Article 53 of the Charter confirms that, where an EU legal act calls for national implementing measures, national authorities and courts remain free to apply national standards of protection of fundamental rights, provided that the level of protection provided for by the Charter, as interpreted by the Court, and the primacy, unity and effectiveness of EU law are not thereby compromised. [Italics added, LB]

This judgment allows for a degree of diversity in implementing measures if the EU law allows for it but otherwise does not allow for diversity. In Melloni the case concerned a provision of the EAW Framework Directive which had explicitly provided for the relevant fundamental rights standard as agreed in a recent amendment to the Directive. The Spanish government had gone along with a provision which did not comply with the national fundamental rights standard. It might have prevented this, if it had made clear what was at stake in terms of national constitutional law. As it had passed the amendment, it had forgone its position, so one might say, and opted for a uniform EU standard.

The formula 'primacy, unity and effectiveness of EU law' is new, or rather the expression 'unity' in it is new. ${ }^{18}$ It must have been introduced consciously, because the in Akerberg Fransson judgment, handed down on the very same day refers to this formula in Melloni (in para. 29).

It is this 'unity' which is intriguing. In earlier formulas the ECJ had used not 'unity' but 'uniformity'.

On a negative reading, this is not significantly different from 'uniformity'. 'Unity in diversity' threatens to be turned into 'unity against

18 The French uses 'la primauté, l'unité et l'effectivité du droit de l'Union'. This is relevant because the expression 'the unity' of Community law was used in some English translations of case law antedating the accession of the UK to the EEC, but is there a mistranslation of 'uniformité'. 
diversity'. In essence, if constitutional fundamental rights cannot be applied under Article 53 of the Charter, if it affects the primacy, unity or effectiveness of EU law, this article is deprived of all meaning.

On a positive reading 'unity' might allow more diversity than 'uniformity'. After all, we have seen that 'unity in diversity' was one of the mottos used in the preambles to the founding Treaties (the Constitutional Treaty): unity does not contradict diversity. This may be the most important message that Melloni signals - even though this may not fully compensate for the fundamental rights deficit which it gives rise to. This may leave some room for further development in different cases.

In particular, in Melloni the ECJ left unanswered what the situation might have been had the Spanish Constitutional Court specified that the relevant fundamental rights norm were part of the constitutional identity of Spain - a point which the advocate general had raised (and dismissed). ${ }^{19}$ So perhaps, given the room which the ECJ leaves for constitutional identity claims, this does leave a glimmer of hope for diversity.

\section{An aside: diversity and the ECHR}

The ECHR provides in principle a uniform minimum standard. So the idea that Melloni applies to other sources of fundamental rights protection than national law would seem not to enter into a discussion of diversity, although it might, in the course of developments in the case law, provide higher protection. In this case the ECJ will have to comply with that higher standard once the EU has become a party to the ECHR, and prior to that on the basis of the interpretative lex specialis of Article 52(3) of the Charter, which imposes the duty to extend the same protection to Charter rights as to equivalent Convention rights. ${ }^{20}$ Uniformity is not the end of the matter, as concerns the ECtHR.

19 See also the case note by de Boer, Case C-399/11, Stefano Melloni v. Ministerio Fiscal, Judgment of the Court (Grand Chamber) of 26 February 2013, Common Market Law Review 2013, vol. 50, issue 4, p. 1083-1103.

20 Art. 52(3) Charter: "In so far as this Charter contains rights which correspond to rights guaranteed by the Convention for the Protection of Human Rights and Fundamental Freedoms, the meaning and scope of those rights shall be the same as those laid down by the said Convention. This provision shall not prevent Union law providing more extensive protection." 
The ECHR provides only a minimum level of protection and allows diversity in terms of higher protection (Art. $53 \mathrm{ECHR}^{21}$ ). This is precisely what the interpretation of the ECJ in Melloni prevents: a human rights standard must in principle be uniform and does not allow for diverse higher protection. Moreover, the case law of the ECtHR, within the uniform minimum level of protection it grants, has built in the 'margin of appreciation' in its review. This can leave a considerable scope of diversity, particularly on issues on which there is no 'common ground' among the states party to the ECHR. So far, the ECJ has not used the 'margin of appreciation' doctrine when applying the EU fundamental rights standard.

\section{Does this mean that there are 'core policies' of a member state on which the EU cannot encroach?}

Whether there are 'core policies' of a member state on which the EU cannot encroach, would seem to require two types of consideration: one is legal and the other is juridico-political.

Legally, the previous sections have suggested that the respect of 'core policies' depends on them being translatable into legal concepts of EU law, which range from the question whether the $\mathrm{EU}$ is competent, to whether the policy in question would provide grounds for a legitimate restriction of free movement rights (in particular under the 'public policy' exception), and the question of whether it belongs to the national or constitutional identity of the member state.

As a rule, it should not come to a confrontation on these issues. This brings me to the legal-political consideration. It is for the actors in the EU decision-making organs to act with constitutional sensitivity. This could lead the institution to prefer the use of instruments such as the directive rather than the regulation, minimum harmonization and normative standards which allow for differentiation and diversity rather than

21 Art. 53 ECHR: "Nothing in this Convention shall be construed as limiting or derogating from any of the human rights and fundamental freedoms which may be ensured under the laws of any High Contracting Party or under any other agreement to which it is a Party." 
uniformity, mutual recognition of different standards rather than unilateral imposition of uniform rules.

It is first of all governments in the Council that are responsible for respecting their own constitutional reservations to further EU integration. ${ }^{22}$ But it is not only these Council members that are involved: if they are about to be outvoted, the consequences must be fully present in the minds of all the other Council members. The European Parliament as co-legislator must of course respect the values on which the EU is founded, which includes the respect of legitimate diversity and local democracy as well as the national, constitutional and political identity of member states. Its members can only be held to account by their own constituency, but there is no reason why there should not be some national-European coordination to render them accountable to their constituency also during their mandate, rather than during elections only.

There are surely 'core policies' of member states on which the EU should not encroach. This is primarily a matter of political assessment, and therefore first of all a matter of constitutionally sensitive political action. This of course does not exclude that courts will be faced with the question whether also legally an alleged encroachment must be sanctioned. This is in a sense secondary in as much as it follows upon the political process having proved unable adequately to display the required constitutional sensitivity.

In its second Lisbon Treaty judgment, the Czech Constitutional Court probably took a wise approach when it refused to follow the line of the BVerfG when challenged to sum up a list of competences which must remain for the member states.

It held:

'Responsibility for these political decisions cannot be shifted onto the Constitutional Court; the Court can make these decisions subject to its review only after they have actually been made on the political level [...]

The Constitutional Court considers that it is exactly the concrete cases that can provide the Court with the relevant framework within which it is possible, by interpretation on a case-by-case basis, to specify the content of the concept of "a sovereign, unitary, and democratic state governed by the rule of law, founded on respect for the rights and freedoms of man and of citizens". ... It is not a

22 This raises questions of its own, see Editorial Comment, After Åkerberg Fransson and Melloni, European Constitutional Law Review 2013, vol. 9, p. 169175. 
manifestation of its arbitrariness, rather on the contrary of its restraint and judicial minimalism, which is understood as a means of limiting judicial power in favour of political procedures, and which prevails over the demand for absolute legal certainty. $^{23}$

23 Judgment of the Constitutional Court of the Czech Republic of 3 November 2009 (Pl. ÚS 29/09: Treaty of Lisbon II) para 111 and 113, available at http://www.usoud.cz/en/decisions/?tx_ttnews[tt_news]=466\&cHash=eedba7ca14 d226b879ccaf91a6dcb276 (checked 06/11/2013). 